\title{
The Effects of Various Choices of IFRS Implementation on the Relevance of Accounting Information
}

\author{
Mohamed Rachid Ouezzani ${ }^{1}$ \& Youssef Alami ${ }^{1}$ \\ ${ }^{1}$ National School of trade and management of tangier, Morocco \\ Correspondence: Mohamed Rachid Ouezzani, National School of Trade and Management of Tangier, Morocco. \\ E-mail: ouezzani@hotmail.com \\ Received: June 21, 2014 \\ Accepted: July 7, 2014 \\ Online Published: July 14, 2014 \\ doi:10.5430/afr.v3n3p12 \\ URL: http://dx.doi.org/10.5430/afr.v3n3p12
}

\begin{abstract}
To adopt IFRS, some jurisdictions as South Africa has chosen a method of implementation IFRS by the adoption of the IASB process while others like Canada, South Korea and the European Union countries opted for outstanding by standard method to implement IFRS. China preferred an incomplete transposition of these standards to the international reference. Faced with these various choices, the question of the impact of the IFRS implementation on the relevance of accounting information remains posed. To answer this question, we have studied the evolution of the relevance of accounting information following the adoption of the IFRS implementation method for a sample composed of listed companies. These firms are from six countries which have opted for different implementation methods of IFRS. The results show a maintain of the high relevance of accounting information for South Africa which opted for an implementation process and an improvement of the relevance for countries which has adopted a standard by standard method of IFRS implementation such as Canada, Germany and Spain excepting South Korea. In China, which conducted an extensive but incomplete convergence of its standards to IFRS, the results demonstrate a decrease in the relevance of the accounting information. Also, comparative analysis of the results shows a better relevance of accounting information for countries which have opted for methods of implementation fairly close to the IFRS.
\end{abstract}

Keywords: IFRS, Implementation, Method, Adoption, Impact

\section{Introduction}

In recent years, a considerable number of countries have begun reforming their accounting system. The European Union has been a pioneer in this field. The Adoption of the Regulation EC 1606/2002 imposing, for the publication of the consolidated financial statements of listed companies, the utilization of the IFRS as adopted by the union. There are even some European Union countries which have made major reforms of their national standards by making them converging to the International accounting standards. The aim is to give a more universal character to the local standards by conforming them to the international requirements. Other countries that are not part of the European Union have made significant reforms. However, analysis of these accounting reforms shows that the process differs from a country to another.

In fact, and according to the study realized by Zeff and Nobes (2010), the process of implementation of IFRS worldwide is quite divergent. Some countries such as China have chosen a convergence, but incomplete, of their national standards to the IFRS. The new accounting standards called 'New Chinese Accounting Standards' - required for listed companies since the 1 January 2007 - are therefore quite similar to the IFRS standards on the major part of points and less on other points (Deloitte 2006).

Other countries like Switzerland allow the use of IFRS as issued by the International Accounting Standard Board optionally for the consolidated accounts of listed companies. For the European Union countries, it comes to refer to the version of IFRS as adopted by the union for the establishment of the consolidated accounts of listed companies. This adopted version may exclude some non adopted standards or contain some modified standards.

For Australia and South Korea, we can speak of complete convergence. In fact, and according to Nobes (2008), the method of implementation of IFRS in Australia can be considered as a very advanced convergence. In South Korea and according to the Korean Council, the K-IFRS and the IFRS are completely identical with the exception of newly published IFRS standards. In this case the temporary differences can delay the perfect similarity. 
A different approach of IFRS implementation is adopted in Canada. Indeed, all the publications of the IASB standards are automatically added to the Canadian standards without making any changes for technical or legal reasons.

Another implementation policy of the IFRS is adopted in countries such as Israel and South Africa. For the latters, we are talking about IFRS implementation process which is the most advanced implementation method. Indeed for this implementation form, the national normalizer adopts the standardization process and therefore automatically adopts the standards that are produced by the normalizer.

Faced with these various situations, the question of the impact of choices of IFRS implementation made by these countries on the quality of the accounting information is posed. To answer this question, we tried to approach the quality of accounting information through the characteristic of relevance that we measured by the model of Ohlson (1995) for countries that have opted for different methods of implementations. The objective of this paper is not simply to measure the relevance of accounting information due to the transition to IFRS in a given country as is the case of several previous studies such as Auer (1996), Bao and Chow (1999), Goldberg and Kim (2005), Hung and Subramanyam (2007); but to do it for several countries that have chosen different methods of also implementation of IFRS to see the effects of each method on the relevance of accounting information.

To achieve this in the present paper, we have first shown the differences between methods of implementation of IFRS according to Zeff and Nobes (2010). Next we have studied the relevance of accounting information through a literature review. Later, a description of the sample of listed companies from South Africa, Canada, South Korea, Germany, Spain and China and of model used will be conducted. The analysis and discussion of results showing greater relevance of accounting information for countries that have opted for an implementation method in accordance with IFRS as issued by the IASB, will be made in the last part of this work

\section{Conceptual and theoretical framework for measuring the impact of the IFRS implementation on the relevance}

\subsection{Study of the different methods of Implementation of IFRS}

Several factors have highlighted the importance of accounting and the need of international accounting harmonization. We may mention the financial scandals of the early 2000s (Enron, WORDCOM ...), and the attractiveness of European and Asian markets that operated with different accounting standards. These facts showed the importance the harmonization. Faced with this situation, the calls to improve financial reporting by donors and international organizations have increased.

Supported by a strong procedural legitimacy of its organs -based on the use of procedures supposed to ensure its impartiality and independence- and a substantial legitimacy -summarized in the possession of a knowledge as well as a technical and scientific expertise (Burlaud and Colasse 2010)-, the IFRS have emerged on the international scene as an accounting and financial referential of high quality.

Also, their adoption by the European Union through the Regulation EC 1606/2002 gave them political legitimacy that these standards could not have had before (Burlaud and Colasse, 2010). This legitimacy prompted several countries outside the European Union to adopt IFRS.

Indeed, following the decision of the European Union to require the IFRS adopted by the union for the publication of consolidated financial statements of listed companies; several countries announced their adoption of the IFRS or their convergence to the IASB standards. To this day, according to the survey of the IFRS Foundation, there are over 101 countries that require the use of IFRS for all, or almost all, of the public interest entities. However, although this number is quite high, more than 21 countries still do not require IFRS for all or most domestic listed companies and use them only in certain measures (Pacter, 2014).

The international analysis of the method of IFRS implementation made by Zeff and Nobes (2010) identified four broad categories of methods that can be called degrees of implementation. The first method is based on a full implementation of the IFRS by the adoption of the process of the normalizer IASB. Thus, standards that are produced by the IASB are automatically adopted without passing through the jurisdictional.

The second degree is the implementation standard by standard. This degree may also be divided into three ranks: The first one is fairly close to the implementation process and is characterized by the adoption of the IFRS published by the IASB without any transformation or deletion but this method requires a passage through an automatically 
national adoption process.

The second rank of the standard by standard implementation is based on a total convergence of the national repository to the IFRS.

The last rank of the standard by standard implementation is founded on an application after modification or non adoption of certain IFRS norms which may decrease the similarity with the IFRS adopted and the IFRS issued by the IASB.

The third degree of the implementation of the IFRS is the optional adoption. It aims to enable the implementation of the IASB standards in specific cases such as the publication of the consolidated accounts of listed companies or well-specified entities.

The fourth and final method is the incomplete convergence. In this implementation method, we try to converge the national referential but by preserving certain provisions of the national accounting referential or to conduct a convergence block.

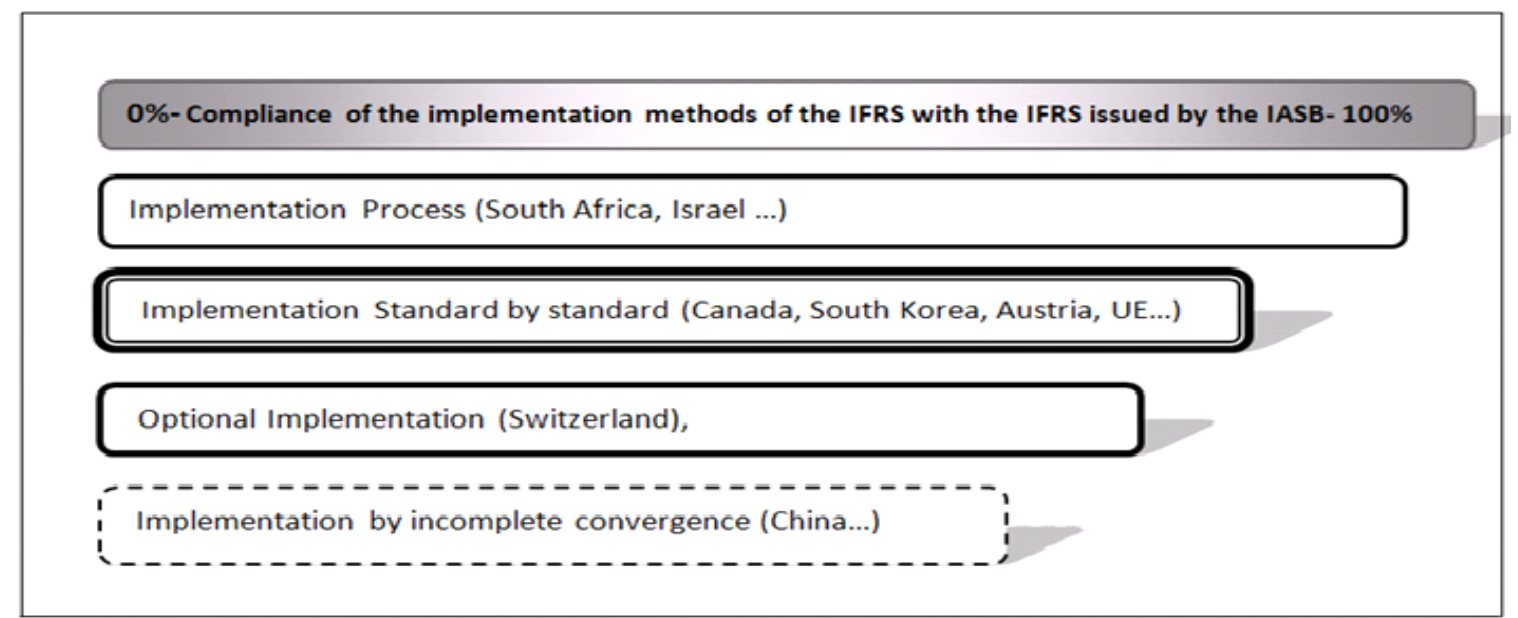

Figure 1. Degree of compliance of the implementation methods of IFRS with the IFRS issued by the IASB -According Zeff and Nobes (2010)- For Consolidated Statements of listed companies

Figure 1 shows schematically the classification established by Zeff and Nobes (2010) of the methods of implementation of IFRS according the degree of compliance with IFRS. So we first have the implementation through the adoption of the IASB process which is the advanced degree of the implementation. Then we have the implementation Standard by Standard. Thereafter we have the optional implementation and the incomplete convergence at last.

\subsection{Theoretical framework of the relevance as a measure of information quality}

The Relevance is one of the four qualitative characteristics of financial information set forth and defined by the IFRS conceptual framework "... The Economic influences decisions of users by helping them to Evaluate past, present and future events." In this framework, information is relevant when it influences the economic decisions of users by supporting them in the evaluation of the past, the present or the future, or helping them to correct past evaluations of events.

Among the early studies of the relevance, we find those of Pop and Rees (1992) who made a reconciliation of accounting standards between United Kingdom. and United States accounting standards and cam to confirm that this reconciliation is able to better explain stock returns. This confirmation was supported by Harris and Muller (1999) which showed that even when compared to IFRS very similar to the U.S. GAAP, the reconciliation results provide relevant information conciliated with the yields. Amir et al. (1993) also studied this quality through reconciliation and showed that investors were using some of the data from the reconciliations. Beckman, Eierle and Brandes (2007) came to the conclusion that the reconciliation between the American, German and International Standards in terms of net profit and equity provides no significant relevance.

Jermakowicz, Prather-Kinsey and Wulf (2007) found that IFRS are very useful compared to German standards hence the importance of reconciliation between the two repositories. Further studies on the possible contribution of two accounting standards by the study of accounting data were established by Harris and Muller (1999), Chen and Sami (2008), Horton and Serafeim (2008) were able to show that the profits of the adjustment between referential 
increases the relevance. The firsts were able to show it by adjusting the British Standards to IFRS standards, while the latters used the IAS and U.S. GAAP.

Other studies focused on the relevance of the information capacity of the standards. Thus, Auer (1996) was able to conclude that the information in IAS was higher in informational material than the Swiss standards. Eccher and Healy (2000) found that IFRS were almost similar in terms of usefulness compared to the Chinese standards. However, Bao and Chow (1999) had previously found that the IAS have better informational relevance that the Chinese standards on profits and equity capitals. Hung and Subramanyam (2007) established than the informational relevance of equity under IFRS was lower than the formulated information according to the German standards. Goldberg and Kim (2005) concluded that the explanatory power of the U.S. standards and of the International accounting Standards was much better than the German standards. These same authors found a different result between the IAS and the U.S. GAAP. According to their study when comparing the relevance of the IAS and the U.S. GAAP, the result of the study wasn't significant.

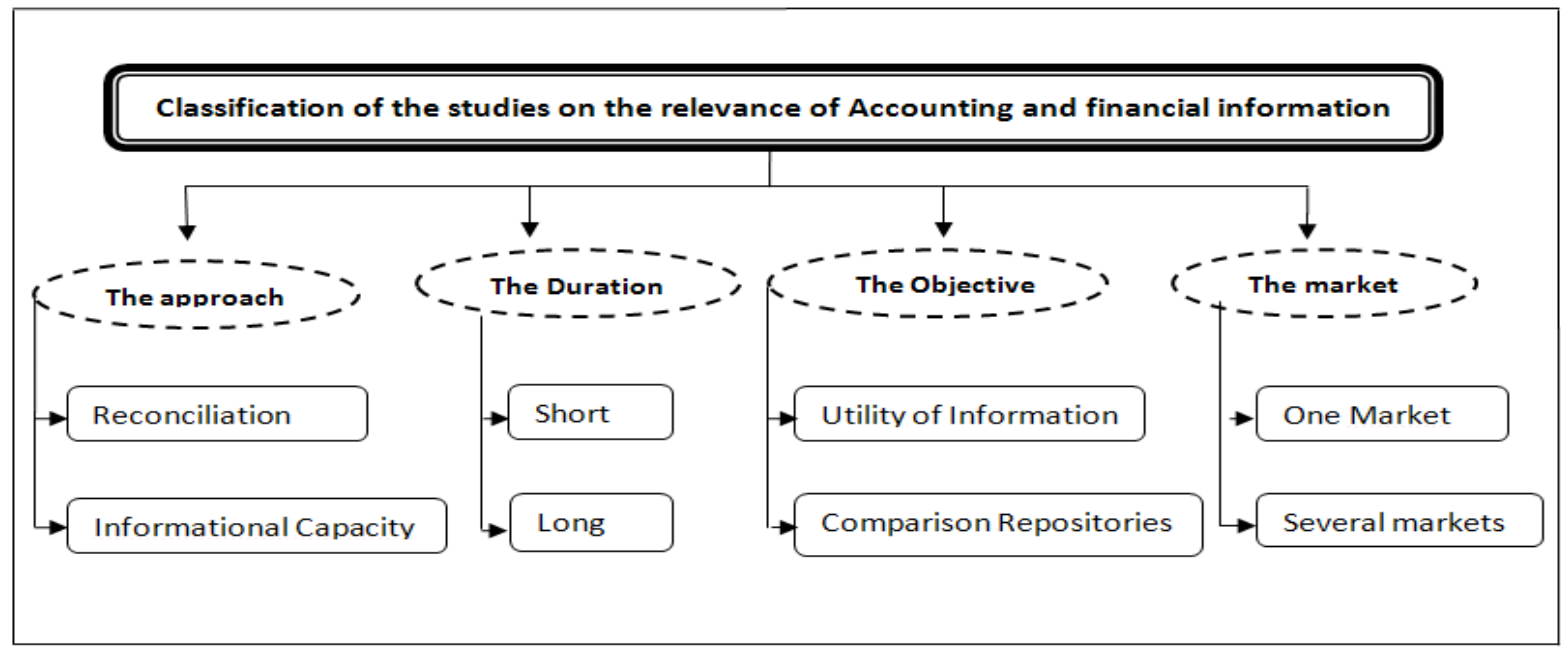

Figure 2. Typology of studies on the relevance of accounting standards

Figure 2 gives a classification of the studies on the relevance of accounting and financial information. These studies may be classified by the approach adopted and in this case we have an approach based on the reconciliation and another one based on the information capacity. A second classification focusing on the period over which the study was conducted can be established and in this case we have two periods, long or short. The Third proposed classification is based on the objective of the study of the relevance which can be the utility of the information or the comparison of the relevance between standards. The fourth classification is based on the number of markets.

Thus, to measure the effect of the IFRS implementation on the quality of accounting information we use an essential characteristic of accounting information which is relevance. The Improvement or deterioration of this characteristic of the accounting information after the application of a method of implementation will allow us to judge its effectiveness.

\section{Methodological framework for measuring the efficiency of the implementation of IFRS through its effect on the relevance of accounting information}

We will now expose the research methodology that we have adopted. We will first explain the model and the research hypotheses. The sample is selected from countries which used different implementation methods of IFRS. Then we will study the statistics of the sample.

\subsection{Proposed model and research hypotheses}

The basic model that we propose to study the efficiency of the implementation method through its impact on the relevance of accounting information is the Ohlson model (1995). Through this model, we analyze the changes in terms of relevance of accounting information following the application of an IFRS implementation method. According to the Ohlson model, the market value of a company is dependent on two main factors: the equity and the earnings. It is worth mentioning that many studies concerning the relevance have used this model. The Ohlson model we use is intended to give an overview of the price of the action of a company by the earnings per share and the equity per share. 
The assessment of relevance is performed by the coefficient of determination R2. This coefficient is designed to measure how well the regression equation is adapted to explain the distribution of points. In our case, we will use it to measure the correlation between stock returns and the accounting information represented by the ratios of equity per share and earnings per share. In case this coefficient is zero, it indicates that the equation of the regression line determines $0 \%$ of the distribution of points and thus the model that we used to explain the stock price does not explain the action price and the relevance of accounting information is null. In the case where the coefficient R2 is 1 , it indicates that the equation of the regression line is able to determine $100 \%$ of the distribution of points and the model that we used to explain the stock price explains the action price. The measure of the relevance of the accounting information will be done before and after the implementation of the IFRS.

The Ohlson model represents the price at the end of the period based on earnings per share and equity per share:

With:

$$
\text { Model (1): } \mathbf{P}_{\mathrm{it}=} \mathbf{B}_{0}+\mathrm{B}_{1} \mathrm{EPS}_{\mathrm{it}}+\mathbf{B}_{2} \mathbf{B V S}_{\mathrm{it}}+\mathrm{e}_{\mathrm{it}}
$$

$\mathbf{P}_{\mathbf{i t}}$ : The share price of firm i at the end of year $\mathrm{t}(31 / 12 / \mathrm{t})$

$\mathbf{E P S}_{\mathrm{it}}$ : The Ratio of earnings per share of firm $\mathrm{i}$ in year $\mathrm{t}$

$\mathbf{B V S}_{\text {it }}$ : The Ratio of equity per share related to firm $\mathrm{i}$ in year $\mathrm{t}$

$\mathbf{e}_{\mathbf{i t}}$ : Other informational pertinence of firm $\mathrm{i}$ in year $\mathrm{t}$

Taking as bases the studies of Zeff and Nobes (2010) who stated that there are four methods of implementation of IFRS which are the implementation process, the standard by standard implementation, the optional implementation and the incomplete convergence; and taking into consideration the existing similarity in terms of the applied standards between the implementation process, the implementation standard by standard and the optional implementation of the IFRS since the standards to be applied are those of the IASB; and considering that several studies on the quality of accounting information which have been made in countries which adopted the methods of implementation fairly close to IFRS showed an improvement in the quality of accounting information following the transition to IFRS as shown by the study of Morais and Curto (2009) who conclude by taking a sample of firms from 14 European countries adopting the standard by standard method, the relevance of the accounting information of firms in these countries has increased following their transition to IFRS; and Viewing the studies of Chalmers et al. (2008) who concluded that the IFRS communicates additional information useful to investors in relation to goodwill that the Australian standards doesn't transmit and who noticed (2011) that the earnings have become more relevant with the IFRS, we formulated the following hypothesis:

H1: The countries adopting the methods of implementation of IFRS which are fairly close to the international standards like the adoption of the process and the implementation standard by standard improves the relevance of the accounting information.

Some studies such as those of Beckman, and Eierle Brandes (2007) came to the conclusion that the reconciliation between the American, German and international standards in terms of net profit and of equity don't improve significantly the relevance. Eccher and Healy (2000) found that IFRS were almost similar in terms of utility to the Chinese standards. Thus we have established the following hypothesis:

H2: The implementation method of the IFRS which is qualified as an incomplete convergence does not improve the relevance of accounting information

\subsection{Characteristics and specificities of the sample}

The sample we have chosen consists of companies listed on the stock markets of six countries that have made during the last decade an implementation of the IFRS with different methods of implementation. The objective is to measure the impact of these various implementation methods on the relevance of accounting information.

Thus, the firms in our sample are listed on the main segment of the following stock markets: South Africa (Implementation Process), Canada - South Korea - Germany and Spain (Implementation standard by standard with 3 degrees: Adoption of the IASB publications -Canada-, complete convergence -South Korea-, Application after adoption and modification of the IFRS -Germany and Spain-), China (Implementation by incomplete convergence). For the stock prices and accounting data, they are from the database S\&P Capital IQ. The observation period is 13 years from 2000 to 2012. However, we have conducted a number of adjustments and eliminations in order to ensure representativeness of the sample and avoid bias that can affect the results of our research. We have therefore.

- Eliminate companies whose observations are not complete in terms of information on the equity, earnings, stock prices and the adopted standards. 
-When the observation on the equity, profits and stock prices are extreme, the observations has been eliminated.

- We have retained the majority of sectors present in the main stock market of six countries. The choice of the implementation method of the IFRS has been retained to have different methods of implementation: the implementation by the adoption process, the Standard by Standard implementation (Adoption of the IASB publications, complete convergence and the application after adoption of the IASB standards) and the incomplete convergence.

- The Implementation by option has not been retained since it does not present a difference in terms of content of the standards. It can be assimilated to the implementation by adopting the publications of the IASB.

Table 1. Sample of companies selected by country

\begin{tabular}{|c|c|c|c|}
\hline Implementation Method & Adoption Process & $\begin{array}{l}\text { Standard by Standard } \\
\text { /Publication IASB }\end{array}$ & $\begin{array}{l}\text { Standard by Standard } \\
\text { /Convergence Complete }\end{array}$ \\
\hline Countries & South Africa & Canada & South Korea \\
\hline Selected Companies & 27 & 399 & 662 \\
\hline Initial observations & 1542 & 18451 & 26470 \\
\hline Observations Retained & 1053 & 15561 & 25818 \\
\hline Implementation Method & \multicolumn{2}{|c|}{$\begin{array}{c}\text { Standard by Standard /IASB with } \\
\text { Suppressions }\end{array}$} & Convergence Incomplete \\
\hline Countries & Germany & Spain & China \\
\hline Selected Companies & 296 & 73 & 657 \\
\hline Initial observations & 12454 & 3045 & 25623 \\
\hline Observations Retained & 11544 & 2843 & 20625 \\
\hline Total of Selected Companies & \multicolumn{3}{|c|}{2114} \\
\hline Total of Initial Observations & \multicolumn{3}{|c|}{87585} \\
\hline Total of Observations Retained & \multicolumn{3}{|c|}{77444} \\
\hline
\end{tabular}

* The observations are from the database S\&P Capital IQ

Table 1 shows the number of firms in the sample by country. We can see the importance described above of the restatements made in the sample for to maximize its adequacy.. Our goal is to avoid any bias.

Tables 2 and 3 show the description of the implementation method and the statistics of the sample. These statistics relate to the share prices of companies selected and the ratios of earnings per share and equity per share. The period used is 13 years ranging from 2000 to 2012 .

Table 2. Description of the implementation

\begin{tabular}{|c|l|l|l|}
\hline Country & Implementation Method & \multicolumn{1}{|c|}{ Date } & \multicolumn{1}{|c|}{ Observation } \\
\hline South Africa & Implementation Process & 01.01 .2005 & $\begin{array}{l}\text { An opening balance sheet based on 2004 accounting } \\
\text { information is necessary. }\end{array}$ \\
\hline Canada & $\begin{array}{l}\text { Standard by standard with } \\
\text { the Adoption of the IASB } \\
\text { publication }\end{array}$ & 01.01 .2011 & $\begin{array}{l}\text { An opening IFRS balance sheet based on 2011 is } \\
\text { necessary. }\end{array}$ \\
\hline South Korea & $\begin{array}{l}\text { Standard by standard with a } \\
\text { Full convergence K-IFRS }\end{array}$ & 01.01 .2011 & $\begin{array}{l}\text { Adopting a full convergence, the K-IFRS balance } \\
\text { sheet is established in 2011 }\end{array}$ \\
\hline Germany & $\begin{array}{l}\text { Standard by standard with } \\
\text { the application of the IFRS } \\
\text { after adoption and deletion. }\end{array}$ & & $\begin{array}{l}\text { An opening balance sheet based on the 2004 is } \\
\text { necessary. }\end{array}$ \\
\hline Spain & $\begin{array}{l}\text { Standard by standard with } \\
\text { the application of the IFRS } \\
\text { after adoption and deletion. }\end{array}$ & 01.01 .2005 & $\begin{array}{l}\text { An opening balance sheet based on the 2004 is } \\
\text { necessary. }\end{array}$ \\
\hline China & $\begin{array}{l}\text { Incomplete convergence to } \\
\text { IFRS }\end{array}$ & 01.01 .2007 & $\begin{array}{l}\text { Adopting an incomplete convergence, the new } \\
\text { balance sheet established according the New } \\
\text { Chinese accounting standards is established in 2007 }\end{array}$ \\
\hline
\end{tabular}


Table 2 shows the dates of transition and the complementary information concerning the transition. The objective is to show the effect of implementation methods on the sample. For example in South Africa, although the date of transition to the IFRS is 01.01 .2005 , an opening balance sheet in 2005 based on 2004 is necessary. So, the 2004 can be included to years with IFRS. For countries adopting a Full or incomplete convergence, the opening balance sheet of the implementation year is excluded since it is not under the converged IFRS.

Table 3. Descriptive statistics of the sample by country

\begin{tabular}{|c|c|c|c|c|c|c|c|c|}
\hline Countries & $\mathrm{N}$ & Average & St. Deviation & Q1 & Median & Q3 & Min & Max \\
\hline South Africa & & & & & & & & \\
\hline $\mathrm{P}$ & 351 & 7.05 & 12.38 & 0.68 & 3.16 & 8.47 & 0.02 & 100.91 \\
\hline EPS & 351 & 0.45 & 1 & 0.04 & 0.22 & 0.69 & 0.8 & 5.75 \\
\hline BVS & 351 & 2.85 & 3.21 & 0.42 & 1.7 & 4.38 & 0.2 & 23.6 \\
\hline Canada & & & & & & & & \\
\hline $\mathrm{P}$ & 6175 & 7,89 & 23,63 & 0,31 & 2,03 & 8,68 & 0 & 563,6 \\
\hline EPS & 6175 & 0,08 & 3,1 & 0,08 & 0,008 & 0,42 & 0.77 & 71,6 \\
\hline BVS & 6175 & 5 & 24 & 0 & 1 & 5 & -20 & 76 \\
\hline South Korea & & & & & & & & \\
\hline $\mathrm{P}$ & 6875 & 26,51 & 291,16 & 1,39 & 3,36 & 11,52 & 0,02 & 23019,56 \\
\hline EPS & 6875 & 0,58 & 130,03 & 0,01 & 0,27 & 1,25 & 0,01 & 2194 \\
\hline BVS & 6875 & 30,59 & 179,25 & 1,97 & 5 & 19,2 & 0,01 & 9344,9 \\
\hline Germany & & & & & & & & \\
\hline $\mathrm{P}$ & 3848 & 40,48 & 256,67 & 3,5 & 9,96 & 26 & 0,066 & 11080 \\
\hline EPS & 3848 & 0,6 & 16,88 & 0 & 0,464 & 2 & $-1176,2$ & 199,6 \\
\hline BVS & 3848 & 19 & 57,09 & 2,41 & 6,4 & 15,1 & -118 & 1295,2 \\
\hline Spain & & & & & & & & \\
\hline $\mathrm{P}$ & 975 & 15.67 & 35.42 & 3.2 & 7.34 & 15.07 & 0.01 & 390 \\
\hline EPS & 975 & 0.76 & 5.42 & 0.08 & 0.38 & 1.12 & 0.85 & 42.6 \\
\hline BVS & 975 & 9.61 & 26.41 & 1.9 & 4.4 & 8.34 & 0.68 & 413.3 \\
\hline China & & & & & & & & \\
\hline $\mathrm{P}$ & 20624 & 0.86 & 2.46 & 0.31 & 0.54 & 0.92 & 0.01 & 96.02 \\
\hline EPS & 20624 & 0.01 & 0.19 & 0 & 0.01 & 0.02 & 0.11 & 5.25 \\
\hline BVS & 20624 & 0.25 & 0.87 & 0 & 0.16 & 0.29 & 0.47 & 26.2 \\
\hline
\end{tabular}

Table 3 provides descriptive statistics of the sample variables (Stock price en of period, EPS, BVS)

\section{Results}

To study the relevance of accounting standards we used the coefficient of determination R2. This coefficient shows the percentage of values explained by the proposed model. We obtained the following results presented by implementation method in Tables 4, 5, 6, 7 and 8:

\subsection{Results of the model for the implementation by adoption of the process -South Africa-}

The model results in South Africa, which has chosen an implementation by the adoption of the IASB process, show a maintaining of the relevance after the implementation of the IFRS. Although the linear regression shows a slight decrease in R2 coefficient between 2000 and 2012, the relatively high value of the above-mentioned coefficient was maintained after the passage to the IFRS via the implementation process. The analysis of the evolution of the coefficient of determination between 2000 and 2004 -before the implementation- shows a slight improvement between 2000 and 2001, a slight decrease of the coefficient in 2002 and a stagnation in 2003. In 2004, the year that knew the start of the implementation of IFRS and therefore the establishment of the opening balance sheet for our South African sample, we see an improvement in the relevance of accounting information. The evolution of the coefficient of determination in the years following the implementation of IFRS was in the interval of $72 \%$ and $93 \%$.

The Examination of the evolution of coefficients R2 of the earnings per share and of the equity per share in South Africa shows an improvement after implementation of IFRS of the equity per share and an opposed result for the 
earnings per share as shown by the Table number 4.

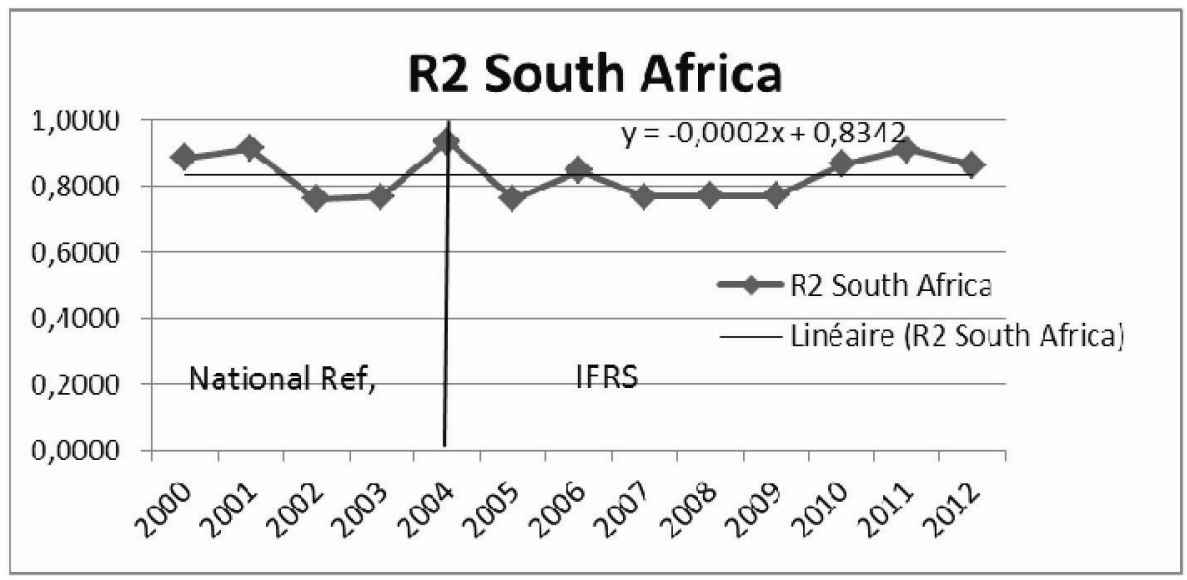

Figure 3. Evolution of R2 following the implementation process of the IFRS in South Africa

The Figure 3 shows the results of the regression in South Africa. The figure indicates a maintaining of the high relevance of accounting information after the implementation of the IFRS.

Table 4. Model results for South Africa (Implementation Process)

\begin{tabular}{|c|c|c|c|c|c|c|c|c|c|c|c|c|c|c|c|c|}
\hline \multirow{2}{*}{ 总 } & \multirow[b]{2}{*}{ Year } & \multicolumn{3}{|c|}{ Constant } & \multicolumn{4}{|c|}{ EPS } & \multicolumn{4}{|c|}{ BVS } & \multirow[b]{2}{*}{ F } & \multirow[b]{2}{*}{ Sig. F } & \multirow[b]{2}{*}{$\mathrm{R} 2$} & \multirow[b]{2}{*}{ D. Watson } \\
\hline & & B0 & $\mathrm{t}$ & Sig. & R2 & B1 & $\mathrm{t}$ & Sig. & R2 & B2 & $\mathrm{t}$ & Sig. & & & & \\
\hline \multirow{15}{*}{ 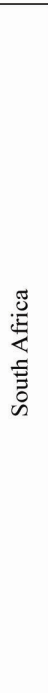 } & 2000 & $-0,0410$ & $-0,0430$ & 0,9660 & 0,8763 & 8,1720 & 9,1910 & 0,0000 & 0,4786 & 0,4340 & 1,3290 & 0,1960 & 92,0180 & 0,0000 & 0,8850 & 2,8510 \\
\hline & 2001 & $-0,6560$ & $-0,9420$ & 0,3560 & 0,8371 & 10,1640 & 11,0400 & 0,0000 & 0,4719 & 1,0590 & 3,4210 & 0,0020 & 126,1220 & 0,0000 & 0,9130 & 1,8210 \\
\hline & 2002 & $-0,8720$ & $-0,7310$ & 0,4720 & 0,7183 & 8,3930 & 4,3960 & 0,0000 & 0,5702 & 1,0970 & 1,9500 & 0,0630 & 38,4050 & 0,0000 & 0,7620 & 1,6370 \\
\hline & 2003 & $-2,6300$ & $-2,0400$ & 0,0530 & 0,4958 & 16,3820 & 5,0040 & 0,0000 & 0,5273 & 1,5420 & 3,1250 & 0,0050 & 39,8640 & 0,0000 & 0,7690 & 1,3010 \\
\hline & 2004* & $-0,0310$ & $-0,0640$ & 0,9500 & 0,0232 & $-3,0750$ & $-3,3630$ & 0,0030 & 0,9060 & 2,7530 & 15,8880 & 0,0000 & 175,8720 & 0,0000 & 0,9360 & 1,8620 \\
\hline & $2005^{*}$ & $-1,3180$ & $-0,7120$ & 0,4830 & 0,1025 & $-2,7710$ & $-1,4500$ & 0,1600 & 0,7007 & 4,1240 & 7,7740 & 0,0000 & 38,3650 & 0,0000 & 0,7620 & 1,0390 \\
\hline & $2006 *$ & $-4,2760$ & $-2,2400$ & 0,0350 & 0,7158 & 7,9280 & 4,0020 & 0,0010 & 0,7394 & 2,8200 & 3,9580 & 0,0010 & 67,1250 & 0,0000 & 0,8480 & 1,4490 \\
\hline & $2007^{*}$ & $-6,0550$ & $-2,2880$ & 0,0310 & 0,4574 & 6,0690 & 2,8480 & 0,0090 & 0,6907 & 4,0360 & 4,3310 & 0,0000 & 39,9060 & 0,0000 & 0,7690 & 2,2610 \\
\hline & $2008^{*}$ & $-1,5530$ & $-1,3380$ & 0,1930 & 0,1560 & 3,5550 & 2,8430 & 0,0090 & 0,6955 & 1,7950 & 3,4910 & 0,0000 & 40,6750 & 0,0000 & 0,7720 & 2,3250 \\
\hline & $2009^{*}$ & $-4,1870$ & $-1,8380$ & 0,0780 & 0,1387 & $-7,2460$ & $-1,1270$ & 0,2710 & 0,7125 & 4,8870 & 6,1970 & 0,0000 & 31,9490 & 0,0000 & 0,7720 & 1,7290 \\
\hline & $2010^{*}$ & $-2,5510$ & $-1,6320$ & 0,1160 & 0,6784 & 1,9020 & 0,6750 & 0,5060 & 0,8628 & 2,7380 & 5,1990 & 0,0000 & 77,1200 & 0,0000 & 0,8650 & 1,9180 \\
\hline & 2011* & $-1,9220$ & $-2,1020$ & 0,0460 & 0,4788 & 1,6380 & 1,5090 & 0,1440 & 0,9034 & 2,1870 & 10,8710 & 0,0000 & 123,9700 & 0,0000 & 0,9120 & 2,2440 \\
\hline & $2012^{*}$ & $-0,8680$ & $-0,8840$ & 0,3860 & 0,0022 & 1,0010 & 0,6510 & 0,5210 & 0,8613 & 2,0150 & 10,4300 & 0,0000 & 76,0550 & 0,0000 & 0,8640 & 2,6420 \\
\hline & $\mu$ Before IFRS & & & & & & & & & & & & & & $0,8322^{* *}$ & \\
\hline & $\mu$ After IFRS & & & & & & & & & & & & & & $0,8287^{* * *}$ & \\
\hline
\end{tabular}

* The information is According to IFRS as published by the IASB

** The average before the IFRS implementation is based on the R2 of years 2000, 2001, 2002 and 2003.

*** The average after the IFRS implementation is based on the R2 of years 2004, 2005, 2006, 2007 and 2008 since the information available for the country before IFRS relates 4 years.

\subsection{Model results for the implementation standard by standard}

The Standard by Standard method of implementation of the IFRS involves three degrees:

4.2.1 Model Results for the method of implementation Standard by Standard with Adoption of the IASB publications -Canada-

In Canada, a country which opted for the method of implementation of the IFRS standard by standard with the adoption of the IASB publications, we find that although 2011 the year following the adoption of the IFRS published by the IASB has known a slight decrease in terms of relevance of accounting information, in 2012 the year that followed, knew an improvement of the coefficient R2 which remains quite high. Indeed, for the two years following the implementation of the IFRS, the coefficient of determination is quite high and exceeds $80 \%$.

The Analysis of variations of the above-mentioned coefficient before the passage to the international accounting 
standards in Canada highlights three tendencies. A First tendency from 2000 to 2006 characterized by a saw teeth evolution with a R2 ranging between $23 \%$ and $60 \%$. A second tendency marked by an improvement in terms of relevance of accounting information is observed between 2006 and 2008 with a R2 ranging between $44 \%$ and $95 \%$. A third downward trend between 2008 and 2010. Also, the comparison between the relevance of the equity per share and the relevance of earnings per share shows that the relevance of the first one according to the model is better than the second as shown by Table number 5 .

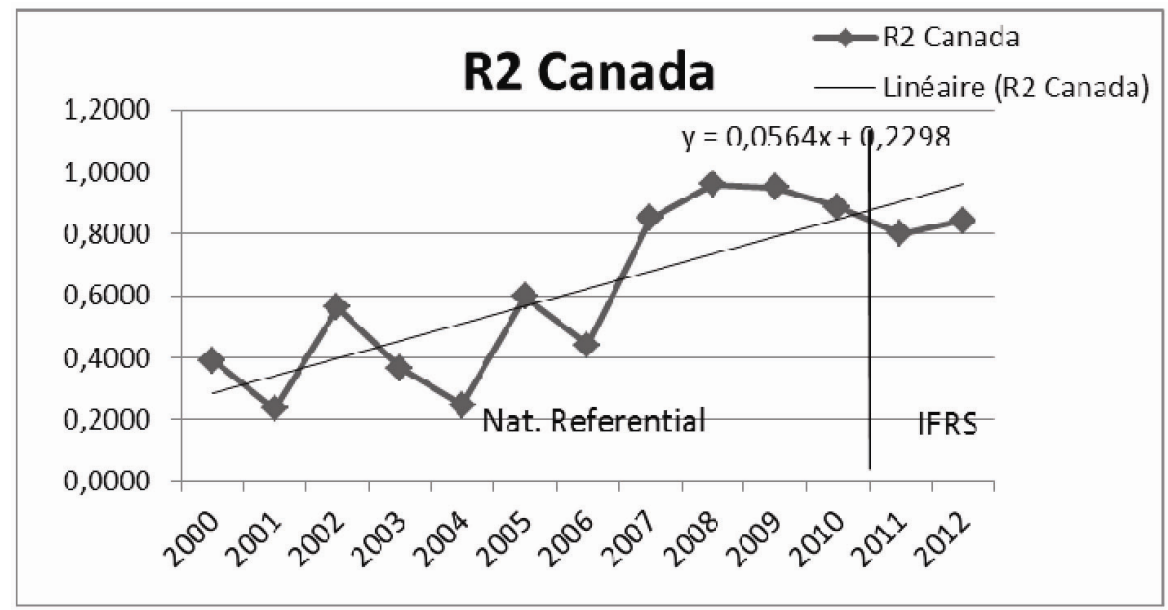

Figure 4. Evolution of R2 following the implementation Standard by Standard / IASB adoption in Canada Figure 4 shows the results of the regression in Canada. The figure shows a general improvement of the relevance of accounting information.

Table 5. Model results for Canada (Implementation standard by standard: Adoption of the IASB publication)

\begin{tabular}{|c|c|c|c|c|c|c|c|c|c|c|c|c|c|c|c|c|}
\hline \multirow{2}{*}{$\begin{array}{l}\vec{E} \\
\hat{0}\end{array}$} & \multirow[b]{2}{*}{ Year } & \multicolumn{3}{|c|}{ Constant } & \multicolumn{4}{|c|}{ EPS } & \multicolumn{4}{|c|}{ BVS } & \multirow[b]{2}{*}{$\mathrm{F}$} & \multirow[b]{2}{*}{ Sig. F } & \multirow[b]{2}{*}{$\mathrm{R} 2$} & \multirow[b]{2}{*}{ D. Watson } \\
\hline & & B0 & $\mathrm{t}$ & Sig. & $\mathrm{R} 2$ & B1 & $\mathrm{t}$ & Sig. & $\mathrm{R} 2$ & B2 & $\mathrm{t}$ & Sig. & & & & \\
\hline \multirow{15}{*}{$\begin{array}{l}\underset{\widetilde{J}}{\tilde{\Xi}} \\
\text { U్ }\end{array}$} & 2000 & 3,6800 & 3,4780 & 0,0001 & 0,0000 & $-8,2450$ & $-5,7895$ & 0,0000 & 0,3574 & 1,3450 & 17,2450 & 0,0000 & 145,2130 & 0,0000 & 0,3900 & 2,0090 \\
\hline & 2001 & 4,5120 & 5,2140 & 0,0000 & 0,1224 & 1,0451 & 0,9470 & 0,2450 & 0,2146 & 0,3470 & 4,8970 & 0,0000 & 74,2145 & 0,0000 & 0,2340 & 2,0147 \\
\hline & 2002 & 2,5040 & 6,0420 & 0,0000 & 0,4576 & $-2,9650$ & $-4,4450$ & 0,0000 & 0,5357 & 0,9750 & 18,7900 & 0,0000 & 303,7240 & 0,0000 & 0,5630 & 1,9870 \\
\hline & 2003 & 3,9500 & 3,4390 & 0,0001 & 0,1276 & $-7,9690$ & $-5,0130$ & 0,0000 & 0,3312 & 1,7800 & 14,1890 & 0,0000 & 136,3710 & 0,0000 & 0,3660 & 2,0060 \\
\hline & 2004 & 6,0550 & 6,2840 & 0,0000 & 0,0283 & 1,0160 & 0,9530 & 0,3410 & 0,2441 & 0,2750 & 4,5710 & 0,0000 & 76,8010 & 0,0000 & 0,2460 & 2,0220 \\
\hline & 2005 & 4,8050 & 5,8980 & 0,0000 & 0,0150 & $-1,7720$ & $-2,7740$ & 0,0060 & 0,5862 & 1,3090 & 13,0760 & 0,0000 & 347,8200 & 0,0000 & 0,5960 & 2,0220 \\
\hline & 2006 & 5,2350 & 4,6460 & 0,0000 & 0,0275 & $-1,9510$ & $-1,3920$ & 0,1640 & 0,4345 & 1,3070 & 5,7340 & 0,0000 & 184,6330 & 0,0000 & 0,4390 & 2,0150 \\
\hline & 2007 & 4,9000 & 11,7630 & 0,0000 & 0,3226 & 2,5050 & 9,2280 & 0,0000 & 0,8214 & 0,5770 & 18,9480 & 0,0000 & 1326,8080 & 0,0000 & 0,8490 & 1,8730 \\
\hline & 2008 & 0,9750 & 6,0270 & 0,0000 & 0,0745 & 1,4680 & 21,9640 & 0,0000 & 0,9113 & 0,7430 & 77,4870 & 0,0000 & 5399,7050 & 0,0000 & 0,9580 & 2,1140 \\
\hline & 2009 & 2,2980 & 10,5000 & 0,0000 & 0,0072 & 3,4090 & 21,4890 & 0,0000 & 0,8965 & 0,6820 & 67,8390 & 0,0000 & 4275,8940 & 0,0000 & 0,9480 & 1,6700 \\
\hline & $2010^{*}$ & 4,1210 & 10,4290 & 0,0000 & 0,6087 & 0,5120 & 1,3080 & 0,0910 & 0,8853 & 0,8200 & 28,5820 & 0,0000 & 1828,4130 & 0,0000 & 0,8860 & 1,6400 \\
\hline & $2011 *$ & 3,1500 & 6,6660 & 0,0000 & 0,0118 & 1,6070 & 5,5700 & 0,0000 & 0,7856 & 0,6950 & 41,0150 & 0,0000 & 936,9720 & 0,0000 & 0,7990 & 1,7480 \\
\hline & $2012 *$ & 5,1240 & 12,5120 & 0,0000 & 0,1457 & 0,6421 & 1,4157 & 0,2145 & 0,8250 & 0,9700 & 30,5470 & 0,0000 & 1478,2140 & 0,0000 & 0,8431 & 1,7510 \\
\hline & $\mu$ Before IFRS & & & & & & & & & & & & & & $0,7985^{* *}$ & \\
\hline & $\mu$ After IFRS & & & & & & & & & & & & & & $0,8427 * * *$ & \\
\hline
\end{tabular}

* The information is According to IFRS as published by the IASB and automatically adopted.

** The average before the IFRS implementation is based on the R2 of years 2006, 2007, 2008 and 2009 since the information available for the country in IFRS relates 3 years.

*** The average after the IFRS implementation is based on the R2 of years 2010, 2011 and 2012 since the information available for the country in IFRS relates 3 years.

4.2.2 Model Results for the method of implementation Standard by Standard with the full convergence -South KoreaThe results of the model for the method of implementation Standard by Standard with a full convergence towards IFRS chosen in South Korea show a decrease in the relevance of accounting information after the adoption of 
Korean IFRS by listed companies of the sample. Indeed, in 2011 and 2012 after the implementation of the Korean version of the IFRS the coefficient R2, which measures the relevance, has decreased from $75 \%$ in 2010 to $63 \%$ and $48 \%$ in 2011 and 2012.

The analysis of the R2 between 2000 and 2012 shows that the latter has greatly improved between 2000 and 2008 from $6 \%$ to $80 \%$ with a tendency to diminution between 2003 and 2006 . The Years 2007 to 2012 were marked by a saw teeth evolution of the R2 with a downward trend after the K-IFRS implementation in 2011.

The examination of the explanatory power of the variables earnings per share and equity per share indicates a better relevance of the earnings per share compared to the equity per share basically after the full convergence to the IFRS as shown by the Table 6 .

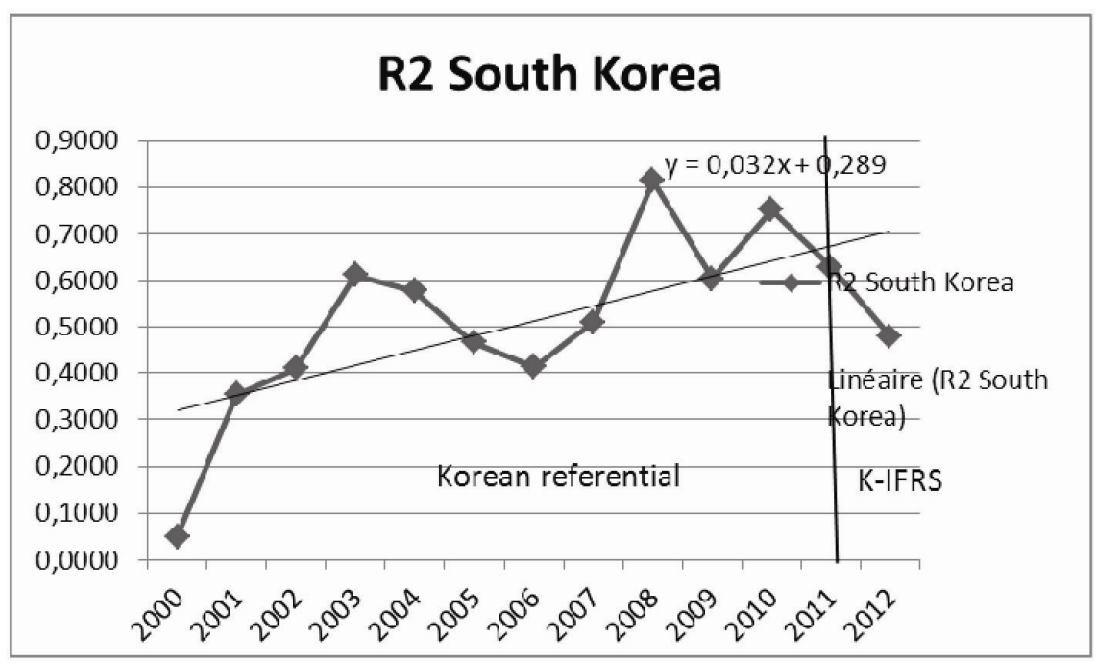

Figure 5. Evolution of R2 following the implementation Standard by Standard / Full Convergence in South Korea

Figure 5 shows the results of the regression in South Korea. The evolution of R2 shows an improvement of relevance before the application of the K-IFRS and a decline in terms of relevance further to the application of the Korean version of IFRS in 2011.

Table 6. Model results for South Korea (Implementation Standard by standard: Full Convergence with the IFRS)

\begin{tabular}{|c|c|c|c|c|c|c|c|c|c|c|c|c|c|c|c|c|}
\hline \multirow{2}{*}{$\begin{array}{l}\text { 音 } \\
\text { 己े }\end{array}$} & \multirow[b]{2}{*}{ Year } & \multicolumn{3}{|c|}{ Constant } & \multicolumn{4}{|c|}{ EPS } & \multicolumn{4}{|c|}{ BVS } & \multirow[b]{2}{*}{$\mathrm{F}$} & \multirow[b]{2}{*}{ Sig. F } & \multirow[b]{2}{*}{ R2 } & \multirow[b]{2}{*}{ D. Watson } \\
\hline & & B0 & $\mathrm{t}$ & Sig. & R2 & B1 & $\mathrm{t}$ & Sig. & $\mathrm{R} 2$ & B2 & $\mathrm{t}$ & Sig. & & & & \\
\hline \multirow{15}{*}{ 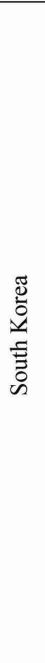 } & 2000 & 9,6900 & 5,6450 & 0,0000 & 0,0070 & 0,2090 & 2,2130 & 0,0270 & 0,0470 & 0,1350 & 5,7280 & 0,0000 & 17,2360 & 0,0000 & 0,0500 & 1,8800 \\
\hline & 2001 & 6,5560 & 3,6440 & 0,0000 & 0,2690 & 0,8680 & 15,5960 & 0,0000 & 0,1040 & 0,3610 & 8,7730 & 0,0000 & 179,6070 & 0,0000 & 0,3530 & 1,8550 \\
\hline & 2002 & 2,4060 & 2,2410 & 0,0250 & 0,7140 & 0,7140 & 12,8490 & 0,0000 & 0,3970 & 0,4180 & 20,8630 & 0,0000 & 228,1390 & 0,0000 & 0,4090 & 1,5320 \\
\hline & 2003 & 0,6900 & 0,5000 & 0,6180 & 0,3450 & 2,4690 & 18,6520 & 0,0000 & 0,5250 & 0,5120 & 26,9860 & 0,0000 & 517,4350 & 0,0000 & 0,6110 & 1,9380 \\
\hline & 2004 & $-0,8350$ & $-0,6080$ & 0,5430 & 0,2480 & 1,7110 & 14,7660 & 0,0000 & 0,5090 & 0,7530 & 26,1350 & 0,0000 & 451,0080 & 0,0000 & 0,5780 & 1,7370 \\
\hline & 2005 & 5,1460 & 2,3300 & 0,0200 & 0,1300 & 0,8610 & 9,9460 & 0,0000 & 0,3970 & 0,7130 & 20,8400 & 0,0000 & 287,4510 & 0,0000 & 0,4660 & 2,1380 \\
\hline & 2006 & 7,0570 & 2,5350 & 0,0110 & 0,0940 & 0,8000 & 8,2550 & 0,0000 & 0,3840 & 0,7040 & 20,2820 & 0,0000 & 231,6400 & 0,0000 & 0,4130 & 2,0910 \\
\hline & 2007 & 7,2550 & 3,3890 & 0,0010 & 0,4610 & 7,0770 & 23,7590 & 0,0000 & 0,3990 & 0,6520 & 20,9520 & 0,0000 & 343,9680 & 0,0000 & 0,5110 & 2,1120 \\
\hline & 2008 & $-0,9330$ & $-0,9680$ & 0,3330 & 0,2450 & 3,5450 & 14,6300 & 0,0000 & 0,7990 & 0,7370 & 51,2380 & 0,0000 & 1439,8210 & 0,0000 & 0,8140 & 1,8660 \\
\hline & 2009 & 3,2710 & 2,1250 & 0,0340 & 0,3580 & 3,2280 & 19,1690 & 0,0000 & 0,4300 & 0,6140 & 22,2990 & 0,0000 & 502,3830 & 0,0000 & 0,6040 & 1,9090 \\
\hline & 2010 & 1,7210 & 1,1540 & 0,2490 & 0,5960 & 4,1670 & 31,2080 & 0,0000 & 0,4500 & 0,7300 & 23,2320 & 0,0000 & 1001,3570 & 0,0000 & 0,7520 & 2,2360 \\
\hline & $2011^{*}$ & 1,9450 & 0,9990 & 0,3180 & 0,5190 & 4,5780 & 26,7060 & 0,0000 & 0,3470 & 0,6750 & 18,7290 & 0,0000 & 556,2610 & 0,0000 & 0,6280 & 2,2020 \\
\hline & $2012^{*}$ & 5,5230 & 2,6940 & 0,0070 & 0,4310 & 5,4740 & 22,3550 & 0,0000 & 0,4120 & 0,5830 & 21,9640 & 0,0000 & 304,1100 & 0,0000 & 0,4800 & 2,0140 \\
\hline & $\mu$ Before K-IFRS & & & & & & & & & & & & & & $0,6200^{* *}$ & \\
\hline & $\mu$ After K-IFRS* & & & & & & & & & & & & & & $0,5540 * * *$ & \\
\hline
\end{tabular}

* The information is According to K-IFRS.

** The average before the IFRS implementation is based on the R2 of years 2008, 2009 and 2010 since the information available for the country in K-IFRS relates 2 years.

*** The average after the IFRS implementation is based on the R2 of years 2011 and 2012 since the information available for the country in K-IFRS relates these 2 years. 
4.2.3 Results of model for the implementation Standard by Standard / Adoption of the IFRS with deletions in Germany and Spain

As members of the European Union, Germany and Spain apply the Regulation EC 1606/2002 requiring for listed companies to publish their financial statements in accordance with IFRS adopted by the European Union.

Although most of IFRS have been adopted by the European Union, it should be noted that these standards are subject to an approval process before being put into effect in the European Union. In case of discrepancy on the approval, this process can take some time which causes a situation of divergence between the standards produced at the IASB and those approved and implemented by the European Union.

In Germany, the results of the model measuring the relevance of the implementation method of the IFRS shows for the Standard by Standard IFRS implementation with deletions a general improvement in the relevance of accounting information following the transition to IFRS as shown by the linear regression of the figure 6 . Indeed, despite the fact that the average calculated on the basis of four years before and five years after implementation in Table 7 below shows a decline in the relevance of accounting information, the linear regression including the all 13 years of the study shows an opposite result.

Year 2004, for which we have the opening balance sheet under IFRS of 2005 year which saw the transition to IFRS, shows a $23 \%$ improvement in the coefficient of determination which increased from $60 \%$ in 2003 to $83 \%$ in 2004 .

Although the above-mentions coefficient has seen a downward trend between 2004 and 2007 passing from $83 \%$ in 2004 to $25 \%$ in 2007 , it has improved at thereafter approaching the bar of $90 \%$ in 2012 .

In terms of comparison between the relevance of the equity per share and the earnings per share, we note that the relevance of the equity per share is higher than the earnings per share as shown by Table number 7 .

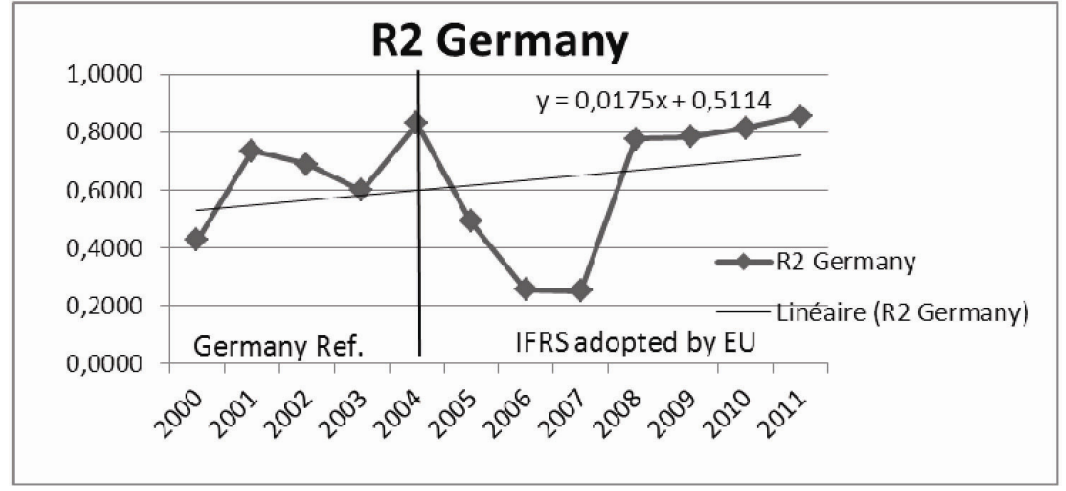

Figure 6. Evolution of R2 following the implementation Standard by Standard / Application of the IFRS standards after adoption and deletion (Germany)

Figure 6 shows the results of the regression in Germany. The R2 results show an improvement of this coefficient following the application of the IFRS adopted by the E.U.

In Spain, a country of the European Union concerned by the Regulation 1606/2001 and which has implemented the IFRS by adopting a Standard by Standard method with deletion, the evolution of the coefficient of determination shows a significant improvement of the relevance of the accounting information for the listed companies of our sample from this country. Indeed, following the implementation of IFRS, the coefficient of determination which varied during the years 2000 until 2003 between 3\% and 90\% has improved and varied between 90\% and 98\% during the years 2004 until 2012 as shown by Table number 8 .

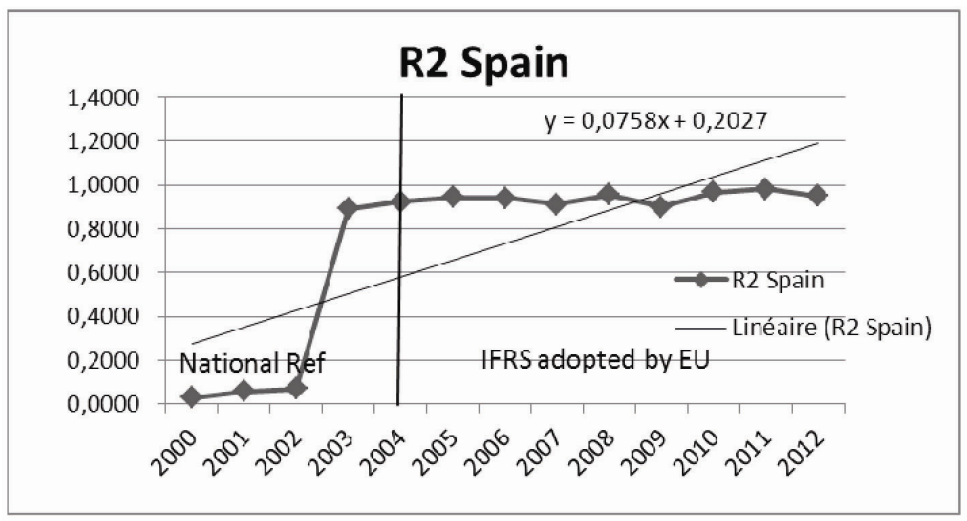

Figure 7. Evolution of R2 following the implementation Standard by Standard / Application of the IFRS standards after adoption and deletion (Spain) 
Figure 7 shows the results of the regression in Spain. The evolution of the R2 shows an improvement of the relevance following the application of the IFRS adopted by the E.U.

\begin{tabular}{|c|c|c|c|c|c|c|c|c|c|c|c|c|c|c|c|c|}
\hline \multirow{2}{*}{ 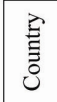 } & \multirow[b]{2}{*}{ Year } & \multicolumn{3}{|c|}{ Constant } & \multicolumn{4}{|c|}{ EPS } & \multicolumn{4}{|c|}{ BVS } & \multirow[b]{2}{*}{ F } & \multirow[b]{2}{*}{ Sig. F } & \multirow[b]{2}{*}{ R2 } & \multirow[b]{2}{*}{ D. Watson } \\
\hline & & B0 & $\mathrm{t}$ & Sig. & R2 & B1 & $\mathrm{t}$ & Sig. & R2 & B2 & $\mathrm{t}$ & Sig. & & & & \\
\hline \multirow{15}{*}{ 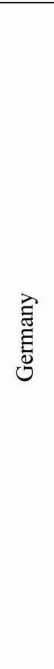 } & 2000 & 9,8320 & 2,3370 & 0,0200 & 0,0760 & 3,3260 & 4,9350 & 0,0000 & 0,4020 & 1,8280 & 14,0550 & 0,0000 & 109,0250 & 0,0000 & 0,4270 & 1,8800 \\
\hline & 2001 & 2,7980 & 1,6790 & 0,0940 & 0,2780 & 8,9630 & 10,6380 & 0,0000 & 0,7360 & 1,3730 & 28,6320 & 0,0000 & 408,5060 & 0,0000 & 0,7360 & 2,0940 \\
\hline & 2002 & 2,1220 & 1,6740 & 0,0950 & 0,6040 & 9,9980 & 21,1720 & 0,0000 & 0,5370 & 0,9280 & 18,4590 & 0,0000 & 326,5680 & 0,0000 & 0,6880 & 2,1360 \\
\hline & 2003 & 4,0510 & 2,0490 & 0,0410 & 0,4990 & 11,1110 & 17,0960 & 0,0000 & 0,4760 & 1,2940 & 16,3410 & 0,0000 & 216,9670 & 0,0000 & 0,5970 & 1,9890 \\
\hline & $2004 *$ & 1,6920 & 0,9570 & 0,3390 & 0,7910 & 11,9910 & 33,3640 & 0,0000 & 0,6460 & 1,7370 & 23,1830 & 0,0000 & 714,0600 & 0,0000 & 0,8300 & 1,9710 \\
\hline & $2005^{*}$ & 8,3170 & 2,8020 & 0,0050 & 0,3360 & 5,6890 & 12,1920 & 0,0000 & 0,4840 & 1,2710 & 16,6000 & 0,0000 & 141,1120 & 0,0000 & 0,4910 & 1,9310 \\
\hline & $2006^{*}$ & 20,2520 & 5,0380 & 0,0000 & 0,1820 & 2,6700 & 8,0760 & 0,0000 & 0,2440 & 0,6510 & 9,7350 & 0,0000 & 49,9180 & 0,0000 & 0,2540 & 1,9030 \\
\hline & $2007 *$ & 24,5590 & 5,8360 & 0,0000 & 0,2480 & 3,7550 & 9,8510 & 0,0000 & 0,2240 & 0,5840 & 9,2150 & 0,0000 & 48,6920 & 0,0000 & 0,2490 & 1,7930 \\
\hline & $2008^{*}$ & 0,1060 & 0,0610 & 0,9520 & 0,1740 & 1,8020 & 7,8630 & 0,0000 & 0,7660 & 1,3200 & 31,0010 & 0,0000 & 507,6350 & 0,0000 & 0,7760 & 1,8660 \\
\hline & $2009^{*}$ & 2,3950 & 1,2970 & 0,1960 & 0,4290 & 5,7050 & 14,8640 & 0,0000 & 0,7650 & 1,3810 & 30,9680 & 0,0000 & 534,0740 & 0,0000 & 0,7850 & 1,8860 \\
\hline & $2010^{*}$ & 2,3700 & 1,1620 & 0,2460 & 0,3630 & 4,8790 & 12,9390 & 0,0000 & 0,7960 & 1,5080 & 33,9220 & 0,0000 & 641,4700 & 0,0000 & 0,8140 & 1,8980 \\
\hline & $2011^{*}$ & 4,8180 & 2,7650 & 0,0060 & 0,6110 & 7,5700 & 21,4690 & 0,0000 & 0,7120 & 0,9500 & 26,9690 & 0,0000 & 862,3580 & 0,0000 & 0,8550 & 1,7920 \\
\hline & $2012 *$ & 5,8940 & 2,9580 & 0,0030 & 0,5950 & 7,0930 & 20,8020 & 0,0000 & 0,8000 & 1,3070 & 34,2410 & 0,0000 & 606,0510 & 0,0000 & 0,8050 & 1,8980 \\
\hline & $\mu$ Before IFRS & & & & & & & & & & & & & & $0,6120^{* *}$ & \\
\hline & $\mu$ After IFRS & & & & & & & & & & & & & & $0,5260 * * *$ & \\
\hline
\end{tabular}

* The information is According to IFRS as published by the IASB

** The average before the IFRS implementation is based on R2 of years 2000, 2001, 2002 and 2003 since the information available for the country in national norms relates 4 years.

*** The average after the IFRS implementation is based on R2 of years 2004, 2005, 2006, 2007 and 2008 since the information available for the country in adopted IFRS relates 4 years.

\begin{tabular}{|c|c|c|c|c|c|c|c|c|c|c|c|c|c|c|c|c|}
\hline \multirow{2}{*}{ 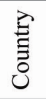 } & \multirow[b]{2}{*}{ Year } & \multicolumn{3}{|c|}{ Constant } & \multicolumn{4}{|c|}{ EPS } & \multicolumn{4}{|c|}{ BVS } & \multirow[b]{2}{*}{$\mathrm{F}$} & \multirow[b]{2}{*}{ Sig. F } & \multirow[b]{2}{*}{$\mathrm{R} 2$} & \multirow[b]{2}{*}{ D. Watson } \\
\hline & & B0 & $\mathrm{t}$ & Sig. & R2 & B1 & $\mathrm{t}$ & Sig. & $\mathrm{R} 2$ & B2 & $\mathrm{t}$ & Sig. & & & & \\
\hline \multirow{15}{*}{$\begin{array}{l}\text { ज्ञ } \\
\text { के }\end{array}$} & 2000 & 8,9510 & 1,8660 & 0,0660 & 0,0060 & 3,4480 & 0,6750 & 0,5020 & 0,0270 & 0,7340 & 1,4030 & 0,1650 & 1,0590 & 0,3520 & 0,0290 & 1,8480 \\
\hline & 2001 & 6,4110 & 1,6600 & 0,1010 & 0,0530 & 7,5390 & 1,9910 & 0,0500 & 0,0480 & 0,8380 & 1,8840 & 0,0640 & 2,2070 & 0,1180 & 0,0590 & 1,9110 \\
\hline & 2002 & 5,9080 & 1,6880 & 0,0960 & 0,0720 & 7,4050 & 2,3440 & 0,0220 & 0,0490 & 0,8410 & 1,9110 & 0,0600 & 2,7130 & 0,0730 & 0,0720 & 1,9190 \\
\hline & 2003 & 5,2670 & 5,1250 & 0,0000 & 0,2680 & 8,0110 & 5,0970 & 0,0000 & 0,8510 & 0,4410 & 20,1720 & 0,0000 & 289,8300 & 0,0000 & 0,8920 & 2,0930 \\
\hline & $2004 *$ & 5,2420 & 4,8070 & 0,0000 & 0,0490 & 4,0760 & 1,9040 & 0,0610 & 0,8870 & 0,5530 & 23,6650 & 0,0000 & 422,4330 & 0,0000 & 0,9230 & 2,1190 \\
\hline & $2005^{*}$ & 4,2540 & 4,2320 & 0,0000 & 0,8430 & 13,9370 & 19,5010 & 0,0000 & 0,8850 & 0,9200 & 23,3780 & 0,0000 & 595,6500 & 0,0000 & 0,9450 & 2,2500 \\
\hline & $2006^{*}$ & 5,7290 & 4,5610 & 0,0000 & 0,4160 & 6,7130 & 7,1190 & 0,0000 & 0,9100 & 1,6590 & 26,7390 & 0,0000 & 578,9590 & 0,0000 & 0,9430 & 2,0810 \\
\hline & $2007 *$ & 1,8590 & 1,0260 & 0,3090 & 0,7400 & 9,4150 & 14,2060 & 0,0000 & 0,7080 & 1,5250 & 13,1170 & 0,0000 & 364,9960 & 0,0000 & 0,9120 & 1,8930 \\
\hline & $2008^{*}$ & 1,1650 & 1,2800 & 0,2050 & 0,9310 & 7,9050 & 30,8900 & 0,0000 & 0,7240 & 1,4930 & 13,6380 & 0,0000 & 772,2530 & 0,0000 & 0,9570 & 1,5050 \\
\hline & $2009 *$ & 4,4370 & 2,0710 & 0,0420 & 0,9000 & 8,6960 & 25,2240 & 0,0000 & 0,7890 & 2,0250 & 16,3140 & 0,0000 & 320,6940 & 0,0000 & 0,9020 & 1,9680 \\
\hline & $2010^{*}$ & $-1,4290$ & $-1,2900$ & 0,2010 & 0,9600 & 9,9060 & 41,0700 & 0,0000 & 0,7970 & 1,8020 & 16,6750 & 0,0000 & 1053,1190 & 0,0000 & 0,9680 & 1,8170 \\
\hline & $2011^{*}$ & $-0,1320$ & $-0,1610$ & 0,8720 & 0,9740 & 8,9110 & 51,9690 & 0,0000 & 0,8130 & 1,8070 & 17,5860 & 0,0000 & 1981,0880 & 0,0000 & 0,9830 & 1,9510 \\
\hline & $2012 *$ & $-1,4420$ & $-1,2130$ & 0,2290 & 0,9030 & 25,7830 & 25,7830 & 0,0000 & 0,8820 & 1,6800 & 23,0590 & 0,0000 & 675,6120 & 0,0000 & 0,9510 & 2,0720 \\
\hline & $\mu$ Before IFRS & & & & & & & & & & & & & & $0,2630^{* *}$ & \\
\hline & $\mu$ After IFRS & & & & & & & & & & & & & & $0,9360 * * *$ & \\
\hline
\end{tabular}

* The information is According to IFRS as published by the IASB

** The average before the IFRS implementation is based on R2 of years 2000, 2001, 2002 and 2003 since the information available for the country in national norms relates 4 years.

*** The average after the IFRS implementation is based on R2 of years 2004, 2005, 2006, 2007 and 2008 since the information available for the country in adopted IFRS relates 4 years. 


\subsection{Results of the model for the method of implementation by incomplete convergence-China-}

In China, a country that has opted for an incomplete convergence to IFRS of the national Chinese accounting standards in 2007, the examination of the evolution of the coefficient of determination indicates a decrease in the relevance of accounting information for listed Chinese companies which applied the new Chinese accounting standards. Indeed, in 2007 the year of the obligation of adoption of the new accounting standards has seen a significant decline in the coefficient of determination R2 passing from 88\% in 2006 to 53\% in 2007.

The years after 2007 experienced a certain stabilization of the R2 at around $80 \%$ which shows a strong relevance of the accounting information following the convergence to IFRS despite the fact that the relevance is lower than before the convergence. In terms of comparison between the explanatory power of the variables earnings per share and equity per share, an examination of the results shows the superiority of the equity per share compared to the earnings per share for both periods before and after convergence to IFRS as shown by Table 9 .

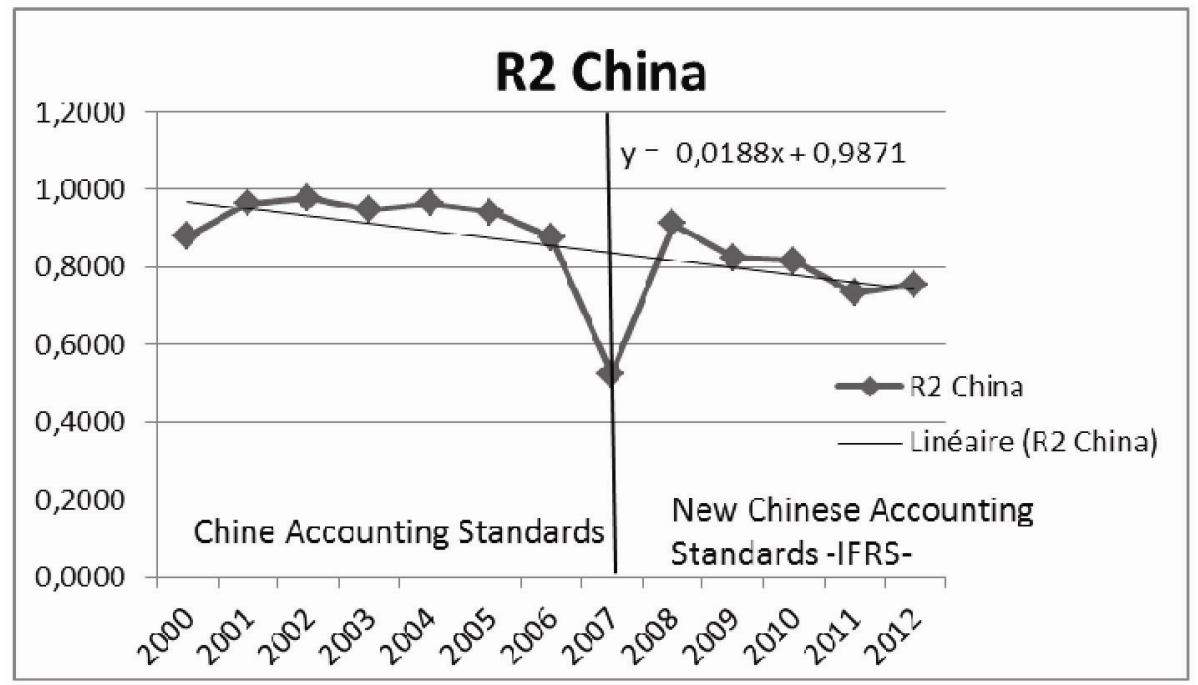

Figure 8. Evolution of R2 following the implementation method by incomplete convergence (China)

Figure 8 shows the results of the regression in China. The evolution of the R2 shows a decline in terms of relevance after the adoption of the new Chinese accounting standards.

Table $N^{\circ}$ 9. Model results for China (Implementation by incomplete convergence)

\begin{tabular}{|c|c|c|c|c|c|c|c|c|c|c|c|c|c|c|c|c|}
\hline \multirow{2}{*}{$\begin{array}{l}\text { 竞 } \\
\text { 言 }\end{array}$} & \multirow[b]{2}{*}{ Year } & \multicolumn{3}{|c|}{ Constant } & \multicolumn{4}{|c|}{ EPS } & \multicolumn{4}{|c|}{ BVS } & \multirow[b]{2}{*}{$\mathrm{F}$} & \multirow[b]{2}{*}{ Sig. F } & \multirow[b]{2}{*}{$\mathrm{R} 2$} & \multirow[b]{2}{*}{ D. Watson } \\
\hline & & B0 & $\mathrm{t}$ & Sig. & $\mathrm{R} 2$ & B1 & $\mathrm{t}$ & Sig. & $\mathrm{R} 2$ & B2 & $\mathrm{t}$ & Sig. & & & & \\
\hline \multirow{15}{*}{ 节 } & 2000 & $-0,4120$ & $-2,6330$ & 0,0100 & 0,1555 & $-1,1000$ & $-0,4770$ & 0,6340 & 0,7537 & 3,0940 & 15,2520 & 0,0000 & 422,7570 & 0,0000 & 0,8800 & 1,8180 \\
\hline & 2001 & $-0,5170$ & $-3,4220$ & 0,0010 & 0,5660 & 36,0620 & 9,5680 & 0,0000 & 0,9065 & 1,1790 & 3,5670 & 0,0010 & 1686,1360 & 0,0000 & 0,9640 & 1,1960 \\
\hline & 2002 & $-0,1270$ & $-1,8290$ & 0,0700 & 0,9279 & 7,8250 & 7,1440 & 0,0000 & 0,9412 & 1,6240 & 11,0660 & 0,0000 & 2838,2480 & 0,0000 & 0,9780 & 1,7440 \\
\hline & 2003 & 0,1020 & 0,6150 & 0,5400 & 0,9241 & 13,4680 & 5,9400 & 0,0000 & 0,9287 & 1,3290 & 2,5050 & 0,0130 & 1310,0700 & 0,0000 & 0,9470 & 2,1520 \\
\hline & 2004 & $-0,1640$ & $-2,6250$ & 0,0090 & 0,7247 & 11,7360 & 20,0070 & 0,0000 & 0,8806 & 1,4130 & 33,8140 & 0,0000 & 2397,4730 & 0,0000 & 0,9640 & 2,0280 \\
\hline & 2005 & $-0,1400$ & $-9,2830$ & 0,0000 & 0,1847 & 13,8810 & 51,7240 & 0,0000 & 0,6965 & 1,1890 & 58,5250 & 0,0000 & 5152,5280 & 0,0000 & 0,9410 & 1,7890 \\
\hline & 2006 & $-0,0440$ & $-1,9410$ & 0,0530 & 0,0056 & 14,2730 & 28,7560 & 0,0000 & 0,7170 & 1,3930 & 39,6240 & 0,0000 & 2276,0760 & 0,0000 & 0,8770 & 2,3030 \\
\hline & $2007 *$ & 0,5400 & 8,4170 & 0,0000 & 0,0665 & 13,2050 & 14,0670 & 0,0000 & 0,3765 & 1,2760 & 10,2780 & 0,0000 & 352,6360 & 0,0000 & 0,5250 & 2,8420 \\
\hline & $2008^{*}$ & 0,1590 & 7,5030 & 0,0000 & 0,4750 & 9,8150 & 49,4560 & 0,0000 & 0,5716 & 0,4280 & \begin{tabular}{|l|}
9,8090 \\
\end{tabular} & 0,0000 & 3293,9080 & 0,0000 & 0,9120 & 1,3790 \\
\hline & $2009^{*}$ & 0,3890 & 8,4960 & 0,0000 & 0,4772 & 1,4570 & 3,8400 & 0,0000 & 0,8199 & 2,2160 & 19,5150 & 0,0000 & 1511,1260 & 0,0000 & 0,8250 & 2,4150 \\
\hline & $2010^{*}$ & 0,3040 & 5,7560 & 0,0000 & 0,3282 & 1,1250 & 2,0260 & 0,0430 & 0,8145 & 2,5070 & 35,7010 & 0,0000 & 1428,8780 & 0,0000 & 0,8170 & 2,0670 \\
\hline & $2011 *$ & 0,1840 & 3,5930 & 0,0000 & 0,0007 & $-1,7660$ & $-3,1120$ & 0,0020 & 0,7287 & 1,9650 & 26,0290 & 0,0000 & 879,7430 & 0,0000 & 0,7340 & 2,3810 \\
\hline & $2012 *$ & 0,2130 & 4,4960 & 0,0000 & 0,4601 & 1,9140 & 2,5680 & 0,0100 & 0,7529 & 1,5160 & 23,7000 & 0,0000 & 994,5600 & 0,0000 & 0,7560 & 2,3910 \\
\hline & $\mu$ Before Convergence & & & & & & & & & & & & & & $0,9358^{* *}$ & \\
\hline & $\mu$ After Convergence & & & & & & & & & & & & & & $0,7615^{* * *}$ & \\
\hline
\end{tabular}

* The information is According to the New Chinese accounting standards

** The average before the IFRS implementation is based on R2 of years 2000, 2001, 2002, 2003, 2004, 2005 and 2006.

*** The average after the IFRS implementation is based on R2 of years 2007, 2008, 2009, 2010, 2011 and 2012. 


\section{Discussion}

The present work aimed to study the effects of methods of implementing IFRS on the relevance of accounting information. To achieve this, we relied on the classification made by Zeff and Nobes (2010) which states that the implementation process of the IFRS globally can be fragmented according to its degree of implementation into four methods of implementation. The first is the advanced implementation of the IFRS by the adoption of the process of the IASB. The second is the standard by standard implementation which includes three levels which are the adoption of the publications of the IASB, the full IFRS convergence and the application after adoption and deletions. The third implementation method is the optional adoption and the fourth and final method is the incomplete convergence. Based on an empirical analysis of the relevance of accounting information according to the Ohlson model (1995) for the period between 2000 and 2012 for six countries that implemented the IFRS by various methods of implementation.

The results show a maintaining of the high level of pertinence in South Africa which has opted for a method of implementation by the adoption of the IASB process. An improvement of the relevance was observed in countries that have opted for a standard by standard implementation except in South Korea. In China, a country that has chosen an implementation by incomplete convergence of the National accounting standards to IFRS, the results show a decline in relevance of accounting information. However, despite this decline it remains modest.

Excepting South Korea which has opted for full convergence, the results show a better relevance of accounting information for the countries which opted for methods of implementation fairly close to the IFRS. Thus, we can note that the results of the model that we used shows a better relevance of accounting information in South Africa, Canada, Germany and Spain which are the countries of our sample that have chosen methods of convergence fairly close to IFRS, compared to China which has opted for an incomplete convergence and for which the results show a lesser relevance.

Moreover, the Ohlson model based on stock prices at the end of the period, earnings per share and capital per share generally shows a certain primacy in terms of relevance of the equity per share compared to the earnings per share. It also informs that the combination of both ratios improves significantly the informational capacity of the accounting information for both local standards and IFRS.

Some of the limitations of this study include the number of countries by method of implementation as well as the number of years comparing the period before and after the implementation of IFRS for certain countries.

The results we found confirm the results of some studies on the relevance and quality of general accounting and of financial information, such as the study of Bartov et al. (2005) who reported a greater relevance of U.S. GAAP and IAS compared to German standards. They contradict other studies such as Hung and Subramanyam (2007) who established that the informational relevance of equity under IFRS was lower than the informational relevance of equity under German standards.

\section{References}

Amir, E., Harris, T.S., \& Venuti, E.K. (1993). A comparison of value relevance of US versus non-USGAAP accounting measures using Form 20-F reconciliations', Journal of Accounting Research Supplement: 31: 230-264. http://dx.doi.org/10.2307/2491172

Auer, K. (1996). Capital market reactions to earnings announcements: empirical evidence on the difference in the information content of IAS-based earnings and EC-Directives-based earnings, The European Accounting Review: 5-4: 587- 623.

Bartov, E, Goldberg, S., \& Kim, M. (2005). Comparative value relevance among German, U.S., and international accounting standards: A German stock market perspective, Journal of Accounting, Auditing and Finance, 20-2: 95-119.

Bao, B., \& Chow, L. (1999). The usefulness of earnings and book value for equity valuation in emerging capital markets: evidence from listed companies in the People's Republic of China, Journal of International Financial Management and Accounting: 10-2: 85-103. http://dx.doi.org/10.1111/1467-646X.00045

Beckman, J., Brandes, C., \& Eierle, B. (2007). German reporting practices: an analysis of reconciliations from German commercial code to IFRS or US GAAP, Advances in International Accounting: 20: 253-94. http://dx.doi.org/10.1016/S0897-3660(07)20009-1

Burlaud, A., \& Colasse, B. (2010). Normalisation comptable internationale : le retour du politique ?, Comptabilité-Contrôle-Audit: 16-3 : 153-175. 
Chalmers, K., Clinch, G., \& Godfrey, J.M. (2008). Adoption of international financial reporting standards impact on the value relevance of intangible assets, Australian Accounting Review: 18: 237-247. http://dx.doi.org/10.1111/j.1835-2561.2008.0028.x

Chen, H., \& Sami, H. (2008). Trading Volume Reaction to the Earnings Reconciliation from IAS to U.S. GAAP, Contemporary Accounting Research: 25-1: 15-53.

Deloitte. (2006). Comparison of IFRSs and New Chinese Accounting Standards A comparison with current PRC GAAP and IFRS, 2006.

Eccher, E., \& Healy P. (2000). The Role of International Accounting Standards in Transitional Economies: A study of the People's Republic of China, Working Paper Series, Massachusetts Institute of Technology.

Jermakowicz, E., Prather-Kinsey, J., \& Wulf, I. (2007). The Value Relevance of Accounting Income Reported by DAX-30 German Companies, Journal of International Financial Management and Accounting,: 18: 3. http://dx.doi.org/10.1111/j.1467-646X.2007.01011.x

Harris, M.S, \& Muller K.A. (1999). The market valuation of IAS versus US-GAAP accounting measures using Form 20-F reconciliations, Journal of Accounting and Economics: 26: 285-312. http://dx.doi.org/10.1016/S0165-4101(99)00003-8

Horton, J., Serafeim, G., \& Serafeim, I. (2008). Does mandatory IFRS adoption improve the information environnement?, Working paper.

Hung, M., \& Subramanyam, K.R. (2007). Financial Statement Effects of the Adoption of International Accounting Standards: The Case of Germany, Review of Accounting Studies: 12-4: 623-657. http://dx.doi.org/10.1007/s11142-007-9049-9

Morais, I.A., \& Curto, J.D. (2009). Mandatory Adoption of IASB Standards: Value Relevance and Country-Specific Factors, Australian Accounting Review: 19-2: 128-143.

Nobes, C. (2008). Accounting Classification in the IFRS Era, Australian Accounting Review: 18-3: 191-198.

Ohlson, J.A. (1995). Earnings, Book Values, and Dividends in Equity Valuation, Contemporary Accounting Research,: 11: 661-687. http://dx.doi.org/10.1111/j.1911-3846.1995.tb00461.x

Pacter, P. (2014). Global Accounting Standards-From Vision to Reality, CPA Journal: 7-10.

Pope, P.F., \& Rees, W. (1992). International Differences in GAAP and The Pricing of Earnings, Journal of International Financial Management and Accounting: 190-219. http://dx.doi.org/10.1111/j.1467-646X.1992.tb00029.x

Zeff, S.A, \& Nobes, C.W. (2010). Commentary: Has Australia (or Any Other Jurisdiction) 'Adopted' IFRS?, Australian Accounting Review: 20-2: 178-184. http://dx.doi.org/10.1111/j.1835-2561.2010.00089.x 